\title{
From Representation to Participation: Rethinking the Intercultural Educational Approach to Folktales
}

\author{
Annette de Bruijn ${ }^{1}$
}

Published online: 22 August 2017

(C) The Author(s) 2017. This article is an open access publication

\begin{abstract}
In multi- or intercultural educational contexts, folktales from around the world are often approached as representative of diverse cultures and used to transmit knowledge and understanding of the literary, social and cultural heritage of those cultures to children. In this article, I present contemporary critical literary, folklore and cultural studies' perspectives to argue that this approach is conceptually problematic, risks reifying reductive notions of cultural difference, and does not take into account children's active role in meaning-making processes. As an alternative, I suggest an understanding of the potential intercultural educational benefits of folktales from diverse cultural traditions in terms of children's intercultural participation. Drawing on qualitative empirical data from a large-scale reading intervention program in Dutch kindergarten and second grade groups, this article illustrates how children from diverse cultural backgrounds use their diversity of knowledge and experience to interpret folktales from diverse cultural traditions. Based on these preliminary findings, I identify several possible intercultural benefits to be gained from valuing children's culturally diverse contributions in today's culturally diverse classrooms. While several limitations need to be taken into account, I argue that further research into the potential intercultural benefits of folktales should not only focus on issues of textual representation, but also on children's active intercultural participation.
\end{abstract}

Annette de Bruijn is a postdoctoral researcher at the Centre for Gender and Diversity, Maastricht University. Combining humanities and social sciences approaches, she studies children's literature in education, focusing on the interplay of various textual and contextual factors in children's situated meaning-making processes. She has published on children's poetry (e.g. Literatuur zonder Leeftijd, 2008; Bookbird, 2015) and is now also looking at a variety of narrative genres.

Annette de Bruijn

annette.debruijn@maastrichtuniversity.nl

1 Centre for Gender and Diversity, Faculty of Arts and Social Sciences, Maastricht University, Grote Gracht 80-82, 6211 SZ Maastricht, The Netherlands 
Keywords Intercultural education · Folktales · Reader response ·

Participation - Cultural diversity

\section{Introduction}

Folktales are often approached as multi- or intercultural educational tools to introduce pupils to the literary, social and cultural heritage of diverse cultures (Young and Ferguson, 1995). Many share the idea that through reading folktales children will not only gain knowledge, but also more empathy and understanding for other cultures. Using folktales as introductions to 'diverse cultures', however, does not necessarily promote intercultural understanding. In fact, it might just as easily reify reductive notions of cultural difference. A more critical perspective on how folktales can contribute to intercultural education is needed to avoid simplified and essentialist approaches to folklore and culture. Critical studies tend to focus on issues of representation in multicultural children's literature, stipulating that "[if] multicultural literature is to ... help readers gain insight into and appreciation for the social groups reflected in the literature, then the literature ought to reflect accurately those groups and their cultures" (Bishop, 1997, p. 16; also Fang et al., 2003; IsekeBarnes, 2009; Kurtz, 1996; Mo and Shen, 1997; Smith and Wiese, 2006; Yokota, 1993). Yet, in addition to issues of textual representation, there are contextual factors that affect the extent to which the assumed intercultural benefits of narrative fiction, including folktales, might be realized in education. I want to address some of those factors.

Situated at the intersections of ethnography, childhood studies, literary studies, and education research (cf. Hoffman, 2010), this article extends existing critical approaches to multicultural children's literature in two directions. Focusing on folktales, I will first draw on contemporary folkloristics and critical literary and cultural studies perspectives to address the conceptual risks of framing these materials as representative of the social, cultural and literary heritage of different cultures. The question is how to avoid these conceptual risks. Secondly, this article explores an understanding of the intercultural educational benefits of folktales from diverse cultural traditions in terms of children's (inter)cultural participation. To illustrate this perspective, I draw on selected empirical data from an extensive oneyear intervention program run in ten primary schools in the Netherlands (2013-2014). Close to 500 children and their teachers in kindergarten and second grade groups (ages 5-8) worked with a cultural reading program containing children's literature rooted in fairy tales, fables, trickster tales, riddles, nonsense verse, musical verse, and religious stories from diverse cultural traditions. The research aim of this intervention program was to study how children's literature can stimulate children's cultural literacy within ethnically, religiously and socioeconomically diverse classrooms without favouring or excluding one specific group of children right from the start.

On the one hand, we expected all children to develop their knowledge of perennial cross-cultural folkloric genres as an important basis of cultural literacy. 
Using a pre-test/post-test design with control groups, we measured the effects of the program on children's knowledge of recurrent features (e.g. characters; tropes; plot structures) of different genres and found that the program had an overall positive effect. On the other hand, we wanted to gain qualitative insight into how children engage with different types of texts, and which factors play a crucial role in their understanding and appreciation of them. This article draws on the latter, suggesting an approach to the intercultural educational value of folktales that foregrounds children's own diverse transactions with these materials.

Drawing on teachers' log entries, classroom observation data, and interviews with teachers I argue that in today's culturally diverse classrooms, it is crucially important to acknowledge children's active role in the process of 'reading'. From their diverse cultural backgrounds children have valuable contributions to make to the intercultural exchange of knowledge and understanding in collaborative 'literary transactions'. Further research into the possible intercultural benefits of this approach is needed. Yet, the findings presented here suggest that it enables young children to build experience in active intercultural participation at a rudimentary level. Moreover, it creates opportunities to engage with and value children's diverse experiences and knowledge in the classroom, whether considered culturally dominant or not.

\section{Folktales in Education: Reducing or Embracing the Complexities of Cultural Diversity?}

Many folkloric genres figure in the storytelling traditions of cultural communities across the world. Within the framework of multi- or intercultural education, this has inspired the use of folktales from around the world as sources of knowledge and understanding of different cultural groups. Published collections of folk- and fairytales, both for children and adults, often provide support for this view as they "presuppose a connection between folklore and culture, either explicitly or implicitly" (Langlois, 2008, p. 312). Titles of folktale collections suggest this connection on a national scale, such as Seki Keigo's Folktales of Japan (1963) and Yolando Pino-Saavedra's Folktales of Chile (1967), or on the level of a regionally or ethnically defined group such as Inea Bushnaq's Arab Folktales (1986) and Richard Erdoes and Alfonso Ortiz's American Indian Myths and Legends (1984). On the internet, countless lesson plans for using folktales to foster cultural understanding are available for all levels of education. In these plans, folktales are often said to represent the ways of life and values of 'the people' of different cultures, or even to teach children from minority groups "about their own cultures" (House, 1993, n.p.).

Similarly, education scholars have approached folktales as a source of knowledge and understanding of different cultures. They are said to teach pupils about the social knowledge and cultural mores of diverse cultural groups, including their customs, values and worldviews, hopes, dreams, and fears (Jarvey et al., 2008; Magliocco, 1992; Mindich Bieger, 1995; Santino, 1991). Folktales are assumed to promote appreciation of the reality of human diversity and empathy with people of 
other cultures (Fuhler et al., 1998; Smith and Wiese, 2006; Young and Ferguson, 1995). These ideas about folktales are often inspired by the work of mythologists, folklorists and anthropologists who study orally transmitted stories as powerfully effective human practices for preserving and passing on cultural knowledge, values and beliefs (Campbell, 1988; in e.g. Jarvey et al., 2008).

However, this is only part of how folklorists conceptualize the link between folktales and cultures nowadays. Crucially, in the wake of broader theoretical developments in anthropology, ethnology and folkloristics, contemporary perspectives stress that the forms, meanings, and functions of narrated materials are largely determined by context (Birkalan-Gedik, 2008; also Goodwin and Duranti, 1992). As explained by folklorist Dan Ben-Amos (1993, pp. 210-211): "The meaning of a text is its meaning in context. The transference of any folklore text to a different literary, historical, or cultural context grants it a new meaning." The context in which folklore is used or presented, 'interprets' and therefore transforms the ways in which audiences perceive it, much like placing an everyday object in an art museum interprets the object as art (p. 212). The question then is what interpretation of folklore and cultural diversity underlies approaches to folktales as sources for knowledge and understanding of diverse cultures within the context of Western education.

Take for instance the books of collected folktales from various national, regional, or ethnic groups for a Western audience that seem to support these educational approaches. In her analysis of the cultural politics of published folktale collections, Kimberly J. Lau (2000, p. 73) warns that these collections necessarily crystallize versions of tales and people, making it hard to escape "essentialist, metonymic representations of the given culture or group, which is assumed to be an integrated, identifiable whole" (see also Nagel, 1994). Because these books are always based on processes of selection and eternalize selected versions of tales-and accompanying ethnographic sketches of cultural communities - in print, they can never truly represent the multiple and changing lives of tales and of peoples. Moreover, folktale collections often implicitly posit the target audience's perspective (such as 'white middle-class American') as the norm by which others are judged and presented as belonging to the category of 'difference'. This category is often defined in terms of spatial as well as temporal distance from the target audience's perspective, i.e. 'from far away and long ago' (Lau, 2000, p. 79). By presenting folktales of 'the cultural other' as representative of the cultural knowledge of that group, folktale collections can convey "the false sense that one can 'know' another culture by purchasing and reading a volume of tales from that group" (p. 80). In this way, the transference of folktales from diverse cultures to a Western 'context of culture' (Malinowski, 1965/ 1935) with its specific literary, historical, and cultural norms, can unintentionally contribute to processes of 'othering'.

In educational approaches that posit folktales as vehicles for conveying knowledge of diverse cultures, published folktale collections often serve as the main sources (e.g. Young and Ferguson, 1995). This can easily lead to a reproduction of essentialist, metonymic representations of the given culture or group as a nationally, regionally or ethnically 'integrated whole'. Educational publications may state that classroom group activities with folktales from different cultures 
around the world, "will permit students from Korea, Jamaica (or other Caribbean islands), Alaskan or Native American cultures, African Americans, and others to see what their people have contributed to literature" (Brooks, 1995, p. 108). This approach foregrounds minority pupils' belonging to 'their people' in national or ethnic contrast with an implied category of 'our people'. Intended as a celebration of diversity, this approach risks 'othering' children by emphasizing national or ethnic difference, and reducing the complexities and dynamics of processes of identification and belonging. Moreover, it suggests to (minority) pupils that what 'their people' have contributed to literature is limited to traditional folktales. However well-intended, these educational approaches risk promoting a limited and essentialist understanding of the cultural or literary heritage of, for example, 'the Korean, Jamaican, or Alaskan people'. This exclusive focus on the 'other', the exotic and traditional, can promote stereotypical or outdated understandings of other cultures which undercut the aim of promoting intercultural appreciation and understanding (Adam and Harper, 2016; Bishop, 1997; David, 2001).

As these risks are so deeply ingrained in the (colonial) history of the collection and study of folklore (Naithani, 2008) the question arises if and how to approach folktales from an intercultural perspective. For that, I argue, we should focus on the 'here-and-now' in specific classroom settings that effectively grant folkloric texts new meaning(s). In these specific contexts, folktales are not only subject to influences of the broader 'context of culture' and to educators' aims, attitudes and approaches, but also to children's participation in active meaning-making processes (Harkin, 2005, p. 413; also Hoffman, 2010, pp. 238-239). According to Louise M. Rosenblatt (1982) readers, whether young or old, bring their past experience of language and of the world to the task of making sense of the text, trying to fit it into a mental framework, or 'cultural schema', as it unfolds: "This implies a constant series of selections from the multiple possibilities offered by the text and their synthesis into an organized meaning" (p. 268, emphasis added). Research shows that children's cultural schemata, based on their past experiences and socialization, are shaped by factors of age, gender, ethnicity, class, and socioeconomic status (e.g. Reynolds et al., 1982). Moreover, children may not be fully socialized into culturally dominant understandings of specific (types of) texts. It is likely, then, that different children make different selections from the multiple possibilities offered by the text: selections that do not necessarily match any publicly constructed meaning of a text, or educators' specific aims and expectations (Rosenblatt, 1982).

In my view, it is exactly in the multiplicity and diversity of children's transactions with folktales that we can find the greatest intercultural educational potential of these materials. To prepare children for life in culturally diverse literate democratic societies, it is of vital importance that they all discover "that texts can make possible [...] intense personal experience" (Rosenblatt, 1982, p. 272), even when their personal experience differs from hegemonic cultural norms, and that all children are given opportunity to actively participate in the intercultural exchange of knowledge and understanding with each other. Below, I will present selected empirical examples from kindergarten and second grade classrooms to illustrate how children from a variety of cultural backgrounds actively engage in meaningmaking processes with folktales, both individually and collaboratively. To 
contextualize these findings, I will first briefly sketch the societal, political and educational context of the Netherlands, and introduce the set-up of the research project that generated the empirical data.

\section{Developing a Cultural Reading Program for Dutch Multi-Ethnic Classrooms}

Since the second half of the twentieth century, the population of the Netherlands has become increasingly ethnically and religiously diverse. On a total population of seventeen million people, $22.1 \%$ is currently counted as immigrant ${ }^{1}$ (CBS, 2016). In the 1960s and 1970s, 'guest laborers' from the south of Europe, Turkey and Morocco were actively recruited by the Dutch government to help restore the economy after the Second World War. Most of these labor migrants stayed, and after the 1970s immigration from these countries continued mainly on the basis of family reunification (Agirdag, 2016). Migrants from Surinam, the Antilles and Aruba and Indonesia came to the Netherlands hoping to find better living conditions and upward social mobility due to the unstable political, economic and/or social circumstances in these former Dutch colonies (Meder and Illes, 2010). While migrants from Morocco, Turkey, the former Dutch Antilles and Surinam still form the largest groups of 'non-Western immigrants', the twenty-first century has brought greater ethnic, socioeconomic and religious diversity to the Dutch population:

In the new millennium, refugees from Africa, Afghanistan and the Middle East, workers from the east of Europe, international students, and wealthy expats have come and are coming to the Netherlands to stay for a longer or shorter period of time and with different intentions. (Leeman, 2017, p. 18)

Initially, increasing ethnic and religious diversity was met with a multiculturalist attitude and integration policy: 'integration with retention of cultural identity'. In the 1980s, intercultural education was introduced in the Netherlands, "to prepare all students for citizenship in a multiethnic context" ${ }^{2}$ (Leeman and Ledoux, 2003, p. 386). It entailed cognitive as well as non-cognitive aims, including the improvement of the educational achievements of students from ethnic minority groups, as well as adjusting the 'white' curriculum to multicultural reality (Agirdag, 2016, p. 284). Research (Leeman, 2008) shows, however, that from the very beginning intercultural education mainly developed in ethnically mixed schools, not in 'white schools', and "suffered from an exotic glorification of other cultures and was often superficial" (p. 54; also Leeman and Ledoux, 2003). Around the beginning of the new millennium, the attitude toward multicultural society changed. Publicist Paul Scheffer unleashed fierce public and political debate with a razor sharp critique of the Dutch multiculturalist attitude and integration policy in an

\footnotetext{
1 This includes first and second generation migrants.

2 Since the 1980s, all primary and secondary schools have had the legal obligation to develop intercultural education to prepare pupils for life in a multicultural society. However, in practice, many schools, especially schools with a white Dutch pupil population, have neglected the development of intercultural education (Leeman, 2008, p. 52).
} 
essay titled 'The Multicultural Drama' (2000). The Dutch political climate and integration policy shifted "from partly neglecting and partly respecting minority culture to viewing it as a handicap and a potential threat to integration" (Leeman, 2008, p. 52; also Entzinger, 2005). In educational policy, attention shifted toward promoting national culture and history (Oostrom, 2006; also Parlevliet, 2016). In the meantime, intercultural education faded from the educational agenda altogether:

In this process, lessons on different cultural heritages and ways of living, colonial histories, racism, narrative accounts on poverty-related migration, inclusive ways of thinking about art and literature by including novelists and artists from the 'non-Western' world, all disappeared from the curriculum. (Leeman, 2017, p. 23)

In the Netherlands all schools are state funded ${ }^{3}$ but differ along pedagogical (Maria Montessori, Helen Parkhurst, Jena plan, Rudolph Steiner etc.) and religious (Catholic, Protestant, Jewish, Islamic, Hindu, secular) lines. Due to the process of secularization since the 1960s, the influence of schools' religious principles on admissions policies has decreased. Similarly, parents' choice of a school is increasingly based on 'quality of education' instead of religious grounds (Dronkers, 1996; Laemers, 1999; Ritzen et al., 1997). As a result, religiously and culturally heterogeneous pupil populations are no longer exclusive to public (non-denominational) schools. ${ }^{4}$ This heterogeneity does create difficulties in the implementation of educational policies. Educational aims such as promoting tolerance of sexual diversity and ethnic-religious tolerance can be perceived as conflicting with religious principles in some schools and with religious and philosophical neutrality in other schools. Individual teachers who try to be sensitive to the religious and cultural diversity among their pupils and avoid possible conflict can also experience such aims as highly challenging (Leeman, 2008, pp. 55-57). In combination with high pressure on schools to meet quality requirements that are almost exclusively based on measurable results in literacy and numeracy, the implementation of (inter)cultural or citizenship education is highly fragmented.

Within this context the research project Emergent Cultural Literacy: Assimilating Children's Literature ${ }^{5}$ (2011-2015) was set up. In this project, a team of researchers studied the use of children's literature to stimulate children's cultural literacy within ethnically, religiously and socio-economically diverse classrooms. We developed an educational intervention program, the Reading Calendar, containing children's literature rooted in folkloric genres that are known and valued within and across different cultures represented in Dutch society. The program contained fairy tales, fables, trickster tales, riddles, nonsense rhymes and musical verse, and stories from religious traditions. Within the genre of trickster tales, for instance, we not only

\footnotetext{
3 The division of public and private education in the Netherlands is based on the form of administration and objectives of the school and not on financing, which is equal for all schools. Public schools are secular, while private schools are almost all denominational (Driessen and van der Slik, 2001).

${ }^{4}$ Of course, this does not mean that all schools are equally heterogeneous. There still exist various gradations, including largely 'white' and 'black' schools, but differences in pupil populations run mostly along geographic lines (urban/rural and within cities also by area).

5 This research project was financed by the Netherlands Organisation for Scientific Research (NWO).
} 
included the trickster Till Eulenspiegel, but also Nasreddin Hodja and Djoha (see Asilioglu, 2008), and the spider Anansi (see Meder and Illes, 2010). Several songs in the program were offered in a variety of languages. Stories from religious traditions were selected on the basis of virtues such as charity and care for animals. These virtues are embedded in Islam as well as Christianity, can be addressed in public schools as general religious and social values, and are recognizable for young children. In this way, we aimed to allow all children to participate in and develop a basic sense of 'shared culture' in which diversity is presented not as oppositional categories like 'majority' versus 'minority' or 'Western' versus 'non-Western', but as variations on common themes.

Over a period of one school year (2013-2014), close to five hundred children and their teachers in kindergarten (ages 5-6) and second grade (ages 7-8) groups in ten primary schools worked with this reading program on a daily basis. The Reading Calendar itself contained one sheet per day showing the title of the day's text and an illustration, accompanied by a teachers' manual containing detailed instructions for classroom treatment of each text. The treatment of each text was chosen not to highlight its being representative of the cultural heritage of a specific group, but to let children actively engage with recurrent features that are shared across a variety of tales within the same genre. Active engagement was stimulated through participatory approaches including classroom discussion, performance, retellings, creating variations, drawing, singing, dancing and clapping. In the selection of schools, we explicitly strived for varying degrees of socio-economic and ethnic diversity. ${ }^{6}$ Public schools, Catholic schools, and one Protestant-Christian, one Islamic, and one Montessori school worked with the program. Classroom observations, teachers' logs and interviews, and a parental questionnaire yielded a range of empirical data on teachers' and children's attitudes, experiences and engagements with the materials. We measured results of the reading program through a pre- and post-test design with control groups, administering a 'Cultural Literacy Test' to all children at the start and at the end of the school year. We measured children's knowledge and understanding of recurrent features of different genres (e.g. characters, plot structure, nonsense strategies). Effects on children's intercultural competences were not measured. The qualitative findings discussed in this article, then, are used by means of illustration and indication of a specific approach to folktales, not 'hard' evidence of its intercultural effects.

The following empirical data show children's and teachers' responses to the trickster tales included in the reading program. The focus on trickster tales is based

\footnotetext{
${ }^{6}$ Following the identification of 'non-Western' ethnic minority groups of the Netherlands' Central Bureau for Statistics, at least $22 \%$ of the children included in our research have at least one parent who was born in Surinam, the Antilles, Turkey or Morocco. Across the research population, 30\% of the children has a non-religious or secular background; $41 \%$ have a Christian (Catholic or Protestant) background; $27 \%$ have an Islamic background. The percentages of ethnic and religious backgrounds are based on a parental questionnaire which was distributed among the parents of all children involved in the research. The response rate was $66.5 \%$ (463 out of 696 questionnaires were completed and returned to us). When it comes to ethnic backgrounds, a lower response rate among immigrant parents due to language differences must be taken into consideration; when it comes to percentages of religious backgrounds, these are higher than the average in the Dutch population because participating schools were partly selected on the basis of religious denomination.
} 
on the fact that they are assumed to be highly suitable for conveying knowledge of 'different cultures' (Brooks, 1995; Young and Ferguson, 1995). This genre is also especially relevant to the Dutch context where Nasreddin Hodja is seen as belonging to the Turkish-Dutch community (Meder, 2002), and Anansi as a particular expression of the cultural identity of the Dutch Creole community (Meder and Illes, 2010).

\section{Moving Beyond Monolithic Representations of Cultural Identities in Kindergarten}

In kindergarten groups, children heard a total of (only) four stories about the trickster(s) Nasreddin Hodja or Djoha as the only trickster(s) in the reading program. These stories were spread across a period of thirty weeks in which children also engaged with twenty-six other texts in a variety of different genres. In the first trickster story, titled 'Djoha Rescues the Moon from the Well', Djoha and his donkey Babori are on their way home when Djoha is shocked to see that the moon has fallen into a well. He wants to save the moon from drowning and put it back where it belongs: among the stars in the evening sky. Djoha throws one end of a rope into the well and tells the moon to hold on tight. Of course, when Djoha starts pulling on his end of the rope, the rope comes loose from the edge of the well and Djoha falls down. Lying on his back, he sees the moon in the sky above and feels very proud of his heroic deed.

Teachers' log entries focused mainly on the question whether or not children believed that the moon had really fallen into the well, as indicated in teachers' manuals. As a trickster tale, the story hinges on the humorous effect of Djoha's misconception (cf. Asilioglu, 2008). In most groups, children recognized the joke and experienced the story as humorous. One of the teachers of the Montessorischool writes: "The children immediately shouted: 'That's not possible, the moon in the well!' They thought it was a funny story." (2322, log week 10) ${ }^{7}$ In the Islamic school, the kindergartners opted for this story to be repeated on Friday because: "Djoha is really stupid, but also funny. He is more stupid than his donkey. He did not get that the moon hadn't fallen into the well, that it was only the shadow." (1021, log week 10) In some groups, children did not see through Djoha's misconception of the situation, but 'getting the joke' is not necessary for appreciating the story. In one group in a Catholic school the children did not like the story, but another group in the same school picked the story as their favourite of the week $(2221 / 2222$, log week 10).

Classroom observation in one of the kindergarten groups ${ }^{8}$ shows that during the reading event the cultural background of Djoha is only brought up once. When the teacher introduces Djoha to the group and mentions that "they also know stories of

\footnotetext{
7 All data have been anonymized for reasons of privacy. Schools, groups, and individual children have all been coded in data files. In this case, ' 23 ' is the school code and ' 22 ' the additional group code.

${ }^{8}$ Roman-Catholic primary school; $45 \%$ of the student population have a non-Western migration background.
} 
Djoha in Morocco", one of the children shows great excitement: "I am from there!" Other than that, children were focused on the plot of the story and thoroughly enjoyed the teacher's lively imitations of Babori's braying. It becomes clear that children's understanding of the text is constructed in a collaborative process. After the story is finished, the teacher says: "Wow, isn't it good that Djoha came by the well at exactly the right time to save the moon? Or did the moon not fall into the well?" One of the boys immediately shakes his head: "No, that is the light and then sometimes you see the moon in it, but ...." The teacher turns to one of the girls: "But, Djoha pulled the moon out of the well, did he not?" The girl remembers how he had thrown the rope into the well and another girl remembers he then saw the moon in the sky. When the teacher again asks if the moon was in the well or not, the first boy gets up from his chair and starts to explain: "Because the moon image is in there, and that is not real ... but the light of the moon." The teacher compliments him and draws on his words to explain how the water reflected the moon (1621, observation 27 November 2013).

Two weeks later, Nasreddin Hodja featured in the kindergarten Reading Calendar in a story titled 'How a Donkey Reads'. In this story, the Hodja uses a clever trick to make the Sultan believe that he managed to teach his donkey how to read a book. What stands out in the teachers' logs is that, in several groups, children immediately recognized 'Djoha'. In the group where children had characterized Djoha as being 'stupid, but also funny' based on the previous story, the teacher now writes: "The children called out 'Djohaaa' in unison when they saw the illustration. They all started laughing and saying 'Stupid Djoha'. [After reading this story they reacted:] Actually, Djoha is also a bit clever. And he is really funny" (1021, log week 12). In each of the stories, the Hodja is attributed a different position and different character traits. He is stupid or foolish in believing the moon needed to be rescued from the well while he is clever in tricking the Sultan to believe he taught his donkey to read. $\mathrm{He}$ is wise in the third story titled 'Hodja Dresses up for a Party' (or 'Fur Coat') in which he reveals people's shallowness in judging others based on their clothing, and he is fooled by someone else in the fourth and final story 'Big Spoon versus Small Spoon'. A teacher in a Catholic school writes: "Nice to see how the children recognize Hodja and remember his adventures from the previous stories. Some children understood that, this time, Hodja was fooled himself" (1621, log week 27).

What is interesting about tricksters in general, is their complexity and multiplicity:

[The trickster] can be noble, majestic, wise and godlike. He can be powerful, brave, knowledgeable and heroic. But at the same time -often during the same story- he can be foolish and stupid, selfish and vain, deceitful and even cruel. And that is the most basic and important truth that lies within all the different Trickster tales. (Hill, 1982, p. 11; as cited in Young and Ferguson, 1995, p. 490)

Even if children were to associate a specific trickster with a specific national, ethnic, religious or cultural identity, tricksters escape reductive stereotypical qualifications constructed through always being portrayed as stupid or clever, as powerful or powerless. If anything, tricksters embody the situated complexities of 'identity' and show how one individual can be many different things depending on the given situation. The qualitative empirical data suggest that kindergarteners can 
recognize a complex character like Nasreddin Hodja or Djoha, and appreciate that he can be stupid and clever and funny all in one. This multiplicity is in itself a fruitful basis for fostering intercultural understanding that goes beyond monolithic representations of cultural identities.

Observations and teachers' log entries also show that children actively look for familiar elements in the trickster stories. In the log entry on 'Djoha Rescues the Moon from the Well' one teacher elaborates on how one boy's remark about 'reflecting water' triggers a discussion about things in which children can see themselves reflected: "'When I'm on the bus, I see myself in the windows of the cars next to me'; 'The white-board in the classroom is also sometimes a mirror'; 'The water tap is a mirror'; 'The legs of the tables and chairs are mirrors'; 'When I am on a bridge, I see myself in the water under the bridge'" (1622, log week 10). Similarly, 'Hodja Dresses Up for a Party' is relatable through children's experience in seeing their parents dress up and in dressing up for a party themselves. One teacher writes: "The children also wear special clothes when they go to a party: a wedding, or Eid al-Fitr" (1021, log week 10). This shows how different children actively interpret story elements using their own cultural schemata, however diverse these may be. Through sharing their diverse cultural knowledge, children might incorporate new understandings of 'a party to dress up for' into their existing schemata. Because they draw on their own experiences, children do not necessarily come to see Hodja as belonging to, for example, Turkish culture. Observation data show that children also empathize with Hodja, understanding the situation in stating: "Nobody wanted to shake his hand", "Stupid!" or "A little strange". "People think he was not joining in the party. I think it's not good, it's sad," said one of the boys. Then, one of the children starts telling about a wedding in France when his uncle was wearing the suit shown on the Reading Calendar (1621, observation 5 February 2014).

There is very little evidence of children in kindergarten groups engaging with elements in these trickster tales as representative of Turkish or Arabic culture. They did interpret elements such as setting based on their own, culturally diverse, experiences and knowledge. By not presenting the tales as belonging to a 'different' culture, the stories offer all children the opportunity to actively engage in the meaning-making process and make valuable contributions to the intercultural exchange of their own knowledge and experience. The data indicate that children as young as five or six can grasp the multiplicity of tricksters' character traits which may prevent simplistic negative or positive stereotyping. Moreover, a story such as 'Hodja Dresses Up for a Party' critically addresses how certain social and cultural norms can effect/lead to exclusion. Because children were able to imagine similar situations, they empathized with Hodja and reacted negatively to people judging him based on his clothing. This basic moral attitude could serve as a starting point for more critical discussions of the societal and political debates surrounding crosscultural differences in clothing at a later stage in education. ${ }^{9}$

\footnotetext{
9 This is of particular relevance in the context of current heated public and political debates on e.g. the wearing of burqas and headscarves in several European countries. Similarly, while these young children expressed support of virtues such as charity, kindness, and care for animals in other stories, at later stages these themes can be revisited in a more critical fashion through texts that reveal their ideological, political and social complexities.
} 


\section{Sharing Cultural Differences and Identifying Generic Similarities in Second Grade}

The Reading Calendar for second grade groups contained four stories about Nasreddin Hodja, four about the spider Anansi, and two about Till Eulenspiegel. Similar to kindergarten groups, the first story about Nasreddin Hodja, 'How a Donkey Reads', is mostly perceived as 'a funny story': the idea that a donkey can read is funny, the gullibility of the Sultan is funny, and of course the teacher making donkey sounds is very funny. The subsequent stories about Hodja increasingly express a 'couleur locale' associated with Middle Eastern countries, and specifically Turkey. The stories for instance contained words like 'bazaar' instead of 'market', the Hodja is addressed as 'Effendi', and reference is made to 'the market square of Aksjehir'.

The following two stories mainly triggered discussions about the Hodja's cleverness and wisdom such as when he manages to 'buy' fabric for new clothes without paying, or when he solves a dispute between a beggar and a shopkeeper with the statement: "The beggar inhaled the smell of your kebab, and paid for it with the sound of his money." The children have difficulty grasping these rather abstract games with logic, but do appreciate the stories because, as one of the teachers writes: "The children recognized Hodja from the previous story. Hodja always plays clever tricks" (1742, log week 3). Here, too, recognition of the main character is supplemented with recognition of elements that relate to children's everyday experiences. A teacher for instance points to the familiarity of children with setting: "The subject spoke to the children: when is the market, etc., even though there were many unknown words" (2343, log week 3 ). Children can relate to 'going to the market', although it is likely that they will have different markets in mind. A teacher in the Islamic school sums up the various reasons children gave for choosing the 'smell of kebab' story as that week's favorite: "The story was funny: the shouting of the beggar-It's funny that they had a fight and shouted-You can learn from it-It's funny that you have to pay for the smell of kebab" (1041, log week 8). While the majority of children agreed that this story was their favourite of the week, none of them named cultural identification as a reason. The variety of reasons reflects how different children make their own selections from the multiple possibilities offered by the story (cf. Rosenblatt, 1982).

The fourth story, titled 'Three Fridays,' did explicitly evoke children's recognition of culturally specific markers, although mostly based on the image on the Reading Calendar. In this story, Nasreddin Hodja is asked by the imam to take over the prayer service in the mosque on three consecutive Fridays. The Hodja's laziness is foregrounded. He does not feel like making an effort and uses a clever play on words to address the people in the mosque in such a way that their supposed stupidity releases him from his duties. On the Reading Calendar, a picture of a mosque was shown to introduce children to the setting of the story. One teacher in the Montessori-school writes: "Very few children knew that it was a mosque. They thought it was from the Efteling." 10 The children were nevertheless able to make sense of the story: "the moral of the story was understood well: 'Hodja did not

10 The Efteling is a very popular fairytale theme park in the Netherlands. 
prepare properly"' (2341, log week 15$)$. In a school with a Catholic denomination, "Children were very enthusiastic about the illustration. They told a lot and even prayed a bit in front of the group" (1641, log week 15). Similarly, in another Catholic school, the illustration and the story triggered children to share religious customs, discovering differences as well as similarities, and "They understood the text well, saying: 'Very silly of Hodja!' and 'That's not allowed!'” (2241, log week $15)$.

Additionally, teachers' log entries show that second graders' appreciation of tricksters does not hinge on differences or similarities in ethnic or religious terms. In the Islamic school, for instance, the teacher notes that the children enjoyed the Caribbean spider Anansi as a 'sly and clever' character. During the reading of the story 'How Anansi Became King of All Stories,' 'they remembered the [recurrent] sentence of the sky god and were able to say it along with me every time" (1041, log week 16). From the second Anansi story ('How Anansi got to Ride Tiger') onward, whether stories were perceived as long and difficult or as exciting and 'cool', children in a public school had formed their opinion about this character: "Stories about Anansi are always fun!" (1141, log week 28). When the children in the Islamic school heard the first story about the trickster Till Eulenspiegel, they immediately identified the type of character: "The story was recognizable for many pupils, 'Like Hodja and Anansi', they said. The children appreciate these stories because they make jokes and fool others" (1041, log week 18). This shows that through their shared experience with the Hodja and Anansi stories, children build up a common knowledge of the genre of trickster tales that allows them to understand new stories not in terms of cultural difference, but in terms of generic similarities.

While children make their own selections from the multiple possibilities offered by the texts to make sense of individual stories, they also gain a shared understanding — and appreciation —of trickster tales. This shared understanding encompasses the multiplicity of each trickster's characteristics, and cross-cultural generic similarities. Although several of the trickster stories contained explicit markers of nationality, ethnicity or religion, it was mainly the illustration of the mosque that triggered some children to spontaneously identify with this religious indicator. This spontaneous recognition of their own religious background is experienced as positive by children who were then able to share their own knowledge and experience with the group. This potentially allows all children to gain cultural knowledge and understanding, not of 'other cultures' but of each other.

\section{In the Light of the Identity of Our School: Challenges and Limitations}

During the final interviews in which teachers were asked about their experiences with the reading program as a whole, one second grade teacher in an ethnically and religiously diverse Catholic school noted:

Specifically stories from the Islamic tradition really appealed to the children with a Muslim background in my group, and all children were interested in hearing stories about that. The same goes for songs in Arabic or another 
language. Children thoroughly enjoy that, especially when they recognize their home language (S24, interview 18 June 2014).

This was a recurrent 'motif' in the interviews and the teachers' logs, specifically with second grade teachers. Another teacher speaks of 'the Muslim stories' that triggered enthusiasm, especially among children with an Islamic background who were happy to tell about customs and celebrations (S11, interview 24 June 2014). A third teacher also reports how she experienced it as very positive that texts related to minority cultures triggered children's mutual interest in each other's backgrounds, customs, home languages, and the like (S22, interview 17 June 2014). These teachers' remarks corroborate what also emerged from the qualitative datasets: several of the texts triggered explicit intercultural exchange between children who felt empowered to share and compare their diverse knowledge and experiences.

However, we also encountered several limitations and challenges. Firstly, teachers pointed to a lack of time and prioritization. As one teacher said it, reading to her group 'is what I enjoy most, but have to drop first' (S16, interview 16 June 2014). When asked whether they experienced working with the program as meaningful, second grade teachers regularly referred to measurable outcomes: "I cannot say; that will have to show in the test results" (S11, interview 24 June 2014). Although most teachers attached 'intrinsic value' to the reading program and relished the children's excitement and engagement, these attitudes reflect the current dominance of high-stakes standardized testing in education and high pressure on teachers to teach the core curriculum. Our Cultural Literacy Test did show overall positive effects of the program on children's knowledge and understanding of recurrent features of folkloric genres. In the final interviews, teachers suggested flexible formats for the program that would make it more workable for them. If a different format were to yield similar results, however, remains to be tested.

Secondly, schools' denominations did complicate the implementation of the program in some cases. One public school did not use/read religious stories as these are seen to conflict with their religious neutrality. The Protestant-Christian school informed us that fairy-tales and other magical stories conflict with their monotheistic religious principles. During the reading program, they also skipped the story 'How Anansi Became King of All Stories' (or 'How the Anansi-Stories Came to the World'). In this story, the spider Anansi uses his trickery and wit to successfully fulfil a series of challenges posed to him by the sky god Nyame to win the golden box containing all stories. As one of the second grade teachers wrote in the log: "In the light of the identity of our school, I skipped this story. There is a sky god in it" (S1741, log week 16). In the Islamic school, arrangements were made with the school's religion teacher for the treatment of stories from the Bible. For pedagogical reasons, this school skipped stories about the celebration of 'Sinterklaas' because most children in the school do not celebrate this at home and teachers feared they might feel left-out when confronted with the fact that other children get presents.

One second grade teacher in a Catholic school expressed her personal discomfort with the multicultural make-up of the reading program. In this teacher's perception, there were "much more Islamic stories than Christian ones"; being a teacher in a Catholic school, she saw this as a shortcoming (S21, interview 5 June 2014). Earlier, 
a text connected to the Turkish holiday Çocuk Bayrami had triggered her to write in the log: "Again some Turkish children tell about a holiday. [...] I notice in myself that I find there to be too many stories about Islam and other countries. I kind of miss the Catholic identity that we convey" (2141, log week 28). Overall, it is noteworthy that teachers' responses pertaining to cultural diversity, positive or negative, reveal an implicit definition of the category of 'difference' as (that which is perceived as) non-Christian and/or non-Western, with explicit emphasis on Islam as 'cultural other'. This is not surprising in the current social and political context. Nor is it based on solid, unchanging, boundaries: 'ethnicity', 'identity' and 'culture' are "continuously negotiated, revised and revitalized, both by ethnic group members themselves as well as by outside observers" (Nagel, 1994, p. 153). From an intercultural perspective it is, however, important to strengthen teachers' awareness of these processes as cultural diversity is a fact they deal with on a dayto-day basis.

\section{From Cultural Representation to Intercultural Participation}

In this age of global migration, many children in many places grow up to become citizens who will, in one way or another, be dealing with ethnic, racial, cultural, religious, social, and/or linguistic diversity, whether locally or globally, personally or professionally. Folktales are one of the many possible educational means considered to stimulate children's intercultural competences in preparation of their future lives. Approaching folktales as representative of the social, cultural, or literary heritage of 'different' cultures can, however, promote stereotypical or outdated understandings of other cultures which undercut intercultural educational aims. Moreover, presuming that children engage with these stories as repositories of knowledge of specific cultures overlooks—or denies them-their active role in meaning-making processes.

In this article, I have argued that we should shift our focus from exclusively thinking about folktales in terms of representation to also thinking about them in terms of (inter)cultural participation. Especially in today's multi-ethnic and multireligious classrooms, it is crucial to be open to and value the contributions that children from diverse cultural backgrounds can make to the transactional process of 'reading' (cf. Rosenblatt, 1982). The qualitative data from the 1-year intervention program presented here, suggest that folktales-as perennial, cross-cultural and lastingly popular-offer all children the opportunity to share their diverse knowledge and experiences in the reading process. Not only does this prevent monolithic and simplistic understandings of stories (and the cultures they are said to represent); it also offers children opportunities to potentially diversify their cultural knowledge in the exchange with other children. Additionally, allowing children to experience a sense of ownership of 'cultural capital', regardless of their majority or minority positions, will likely stimulate their active engagement and motivation.

Of course, one limitation is that this approach depends on culturally diverse classrooms. However, 'diversity' is not limited to ethnicity or religion, and children will still draw on their own specific knowledge and experiences in meaning-making 
processes and potentially benefit from engaging with other children's perspectives. Conceptually, understanding the intercultural educational benefits of folktales in terms of (inter)cultural participation allows us to move away from an approach that figures these texts as "repositories of stable meaning", and children as a "passive audience" that should retrieve that meaning (cf. Harkin, 2005, p. 413). Equally, there is reason to accept limitations for any long-term effects of such programs in creating 'ideal intercultural citizens' as there are many other contexts and factors that come into play. Yet, enabling children to actively participate in and contribute to meaning-making processes from an early age, potentially diversifying their cultural schemata through intercultural exchange of knowledge and experience, as well as gaining a sense of empowerment and ownership of cultural capital even when coming from a minority position, are all possible short-term effects of this approach to folktales that are worth investigating further.

Acknowledgements The study on which this article is based, was part of the research project 'Emergent Cultural Literacy: Assimilating Children's Literature' funded by the Netherlands Organisation for Scientific Research (NWO).

Funding The study on which this article is based, was part of the research project 'Emergent Cultural Literacy: Assimilating Children's Literature' funded by the Netherlands Organisation for Scientific Research (NWO) (Project No.: 360-30-210; main applicant: Prof. Dr. E. Wesseling, Maastricht University). The author of this article was one of the doctoral researchers within this project.

\section{Compliance with Ethical Standards}

Conflict of Interest The author declares that she has no conflict of interest.

Human and Animal Rights and Informed Consent All schools that participated in this study chose to do so based on information about the content and aims of the intervention program and, after their expression of interest, more detailed information on the research instruments of data collection and measures to ensure data protection and privacy of participants. Heads of schools as well as teachers signed an agreement about their participation which stated their and our (the research team) commitments. All children involved in this study had been informed by their teachers and received a letter with information about the intervention program for their parents or legal guardians. The letter included the possibility to object to children's participation in the Cultural Literacy Test and video registration. During the Test, when children expressed the strong wish to stop, we did so and guided them back to their classrooms. The study was carried out in compliance with The Netherlands Code of Conduct for Academic Practice (2004) and data collection was carried out in regard of participants' privacy, well-being and general informed consent or assent.

Open Access This article is distributed under the terms of the Creative Commons Attribution 4.0 International License (http://creativecommons.org/licenses/by/4.0/), which permits unrestricted use, distribution, and reproduction in any medium, provided you give appropriate credit to the original author(s) and the source, provide a link to the Creative Commons license, and indicate if changes were made.

\section{References}

Adam, Helen and Harper, Laurie. (2016). Assessing and Selecting Culturally Diverse Literature for the Classroom. Practical Literacy: The Early \& Primary Years, 21(2), 10-14. 
Agirdag, Orhan (2016). Etnische Diversiteit in het Onderwijs. In B. Eidhof, M. Van Houtte and M. Vermeulen (Eds.), Sociologen over Onderwijs. Inzichten, Praktijken en Kritieken (pp. 281-308). Antwerpen: Garant.

Asilioglu, Bayram. (2008). The Educational Value of Nasreddin Hodja's Anecdotes. Children's Literature in Education, 39(1), 1-8.

Ben-Amos, Dan. (1993). "Context" in Context. Western Folklore (Special Issue Theorizing Folklore: Toward New perspectives on the Politics of Culture), 52(2/4), 209-226.

Birkalan-Gedik, Hande. (2008). Context. In Donald Haase (Ed.), The Greenwood Encyclopedia of Folktales and Fairy Tales, Volumes 1-3 (pp. 233-235). Westport (CT)/London: Greenwood Press.

Bishop, Rudine S. (1997). Selecting Literature for a Multicultural Curriculum. In Violet J. Harris (Ed.), Using Multiethnic Literature in the K-8 Classroom (pp. 1-19). Norwood:Christopher-Gordon Publishers.

Brooks, Charlotte K. (1995). World-Wide Tricksters. The English Journal, 84(6), 108-109.

Campbell, Joseph. (1988). The Power of Myth New York (NY):Doubleday.

CBS. (2016, November 18). StatLine: Bevolking; Geslacht, Leeftijd, Nationaliteit en Regio. Den Haag/ Heerlen: Centraal Bureau voor de Statistiek.

David, Robert G. (2001). Representing the Inuit in Contemporary British and Canadian Juvenile Nonfiction. Children's Literature in Education, 32(2), 139-154.

Driessen, Geert and van der Slik, Frans. (2001). Religion, Denomination, and Education in the Netherlands: Cognitive and Noncognitive Outcomes after an Era of Secularization. Journal for the Scientific Study of Religion, 40(4), 561-572.

Dronkers, Jaap. (1996). Dutch Public and Religious Schools between State and Market: A Balance between Parental Choice and National Policy? In Dietrich Benner, Adolf Kell and Dieter Lenzen (Eds.), Bildung zwischen Staat und Markt (pp. 51-66). Weinheim/Basel:Beltz Verlag.

Entzinger, Han. (2005). Changing the Rules While the Game is On: From Multiculturalism to Assimilation in the Netherlands. In Y. Michael Bodemann and Gökçe Yurdakul (Eds.), Migration, Citizenship, Ethnos: Incorporation Regimes in Germany, Western Europe and North America (pp. 121-144). New York: Palgrave Macmillan.

Fang, Zhihui, Danling, Fu and Lamme, Linda Leonard. (2003). The Trivialization and Misuse of Multicultural Literature: Issues of Representation and Communication. In Dana L. Fox and Kathy G. Short (Eds.), Stories Matter: The Complexity of Cultural Authenticity in Children's Literature (pp. 284-303). Urbana (IL):National Council of Teachers of English.

Fuhler, Carol J., Farris, Pamela J. and Hatch, Lynda. (1998). Learning about World Cultures through Folktales. Social Studies and the Young Learner, 11(1), 23-25.

Goodwin, Charles and Duranti, Alessandro. (1992). Rethinking Context: Introduction. In Charles Goodwin and Alessandro Duranti (Eds.), Rethinking Context: Language as an Interactive Phenomenon (pp. 1-42). Cambridge:Cambridge University Press.

Harkin, Patricia. (2005). The Reception of Reader-Response Theory. College Composition and Communication, 56(3), 410-425.

Hill, David. (1982). Introduction. In G. Robinson (Ed.), Raven the Trickster: Legends of the North American Indians (pp. 9-12). New York: Atheneum.

Hoffman, A.Robin. (2010). The BFG and the Spaghetti Book Club: A Case Study of Children as Critics. Children's Literature in Education, 41(3), 234-250.

House, Christine Y. (1993). Curriculum Unit 93.02.05: Cultural Understanding through Folklore. Accessed March 28, 2017 from http://teachersinstitute.yale.edu/curriculum/units/1993/2/93.02.05.x. html.

Iseke-Barnes, Judy. (2009). Unsettling Fictions: Disrupting Popular Discourses and Trickster Tales in Books for Children. Journal of the Canadian Association for Curriculum Studies, 7(1), $24-57$.

Jarvey, Marya, McKeough, Anne and Pyryt, Michael C. (2008). Teaching Trickster Tales: A Comparison of Instructional Formats. Research in the Teaching of English, 43(1), 42-73.

Kurtz, Jane. (1996). Multicultural Children's Books: The Subtle Tug-of-War. School Library Journal, 42(2), 40-41.

Laemers, Miek. (1999). Schoolkeuzevrijheid: Veranderingen in Betekenis en Reikwijdte Ubbergen:Tandem Felix.

Langlois, Janet L. (2008). Ethnographic Approaches. In Donald Haase (Ed.), The Greenwood Encyclopedia of Folktales and Fairy Tales, Volumes 1-3 (pp. 311-313). Westport (CT)/London: Greenwood Press. 
Lau, Kimberly J. (2000). Serial Logic: Folklore and Difference in the Age of Feel-Good Multiculturalism. The Journal of American Folklore, 113(447), 70-82.

Leeman, Yvonne. (2017). Whither Cultural Diversity and Intercultural Education in the Netherlands? In Carol Reid and Jae Major (Eds.), Global Teaching: Southern Perspectives on Teachers Working with Diversity (pp. 17-34). New York:Palgrave Macmillan.

Leeman, Yvonne. (2008). Education and Diversity in the Netherlands. European Educational Research Journal, 7(1), 50-59.

Leeman, Yvonne and Ledoux, Guuske. (2003). Intercultural Education in Dutch Schools. Curriculum Inquiry, 33(4), 385-399.

Magliocco, Sabina. (1992). Folklore and Language Teaching: Preliminary Remarks and Practical Suggestions. Italica, 69(4), 451-465.

Malinowski, Bronislaw. (1965/1935). The Language of Magic and Gardening. Coral Gardens and Their Magic, Volume II. Bloomington: Indiana University Press.

Meder, Theo. (2002). De Dochter van Hodja. Of: Welke Verhalen nemen Nederlanders over van Allochtonen?. In Hans Bennis, Guus Extra, Pieter Muysken and Jacomine Nortier. (Eds.), Een Buurt in Beweging. Talen en Culturen in het Utrechtse Lombok en Transvaal (pp. 49-66). Amsterdam: Aksant.

Meder, Theo and Flora Illes. (2010). Anansi comes to Holland. The Trickster Spider as a dynamic Icon of Ethnic Identity. Quotidian: Journal for the Study of Everyday Life, 2(1), 20-63.

Mindich Bieger, Elaine. (1995). Promoting Multicultural Education through a Literature-Based Approach. The Reading Teacher, 49(4), 308-312.

Mo, Weimin and Shen, Wenju. (1997). Reexamining the Issue of Authenticity in Picture Books. Children's Literature in Education, 28(2), 85-93.

Nagel, Joane. (1994). Constructing Ethnicity: Creating and Recreating Ethnic Identity and Culture. Social Problems (Special Issue on Immigration, Race, and Ethnicity in America), 41(1), 152-176.

Naithani, Sadhana. (2008). Colonialism. In Donald Haase (Ed.), The Greenwood Encyclopedia of Folktales and Fairy Tales, Volumes 1-3 (pp. 222-226). Westport/London: Greenwood Press.

Oostrom, Frits van. (2006). Entoen.nu De Canon van Nederland. Rapport van de Commissie Ontwikkeling Nederlandse Canon. Deel A. The Hague: Ministerie van OCW.

Parlevliet, Sanne. (2016). Is that Us? Dealing with the 'Black' Pages of History in Historical Fiction for Children. Children's Literature in Education, 47, 343-356.

Reynolds, Ralph E., Taylor, Marsha A., Steffensen, Margaret S., Shirey, Larry L. and Anderson, Richard C. (1982). Cultural Schemata and Reading Comprehension. Reading Research Quarterly, 17(3), 353-366.

Ritzen, Jozef M.M., van Dommelen, Jan and De Vijlder, Frans J. (1997). School Finance and School Choice in the Netherlands. Economics of Education Review, 16(3), 329-335.

Rosenblatt, Louise M. (1982). The Literary Transaction: Evocation and Response. Theory into Practice (Children's Literature), 21(4), 268-277.

Santino, Betsy H. (1991). Improving Multicultural Awareness and Story Comprehension with Folktales (in the Classroom). The Reading Teacher, 45(1), 77-79.

Scheffer, Paul. (2000, January 29). Het Multiculturele Drama. NRC Handelsblad.

Smith, Jane and Wiese, Patricia. (2006). Authenticating Children's Literature: Raising Cultural Awareness with an Inquiry-Based Project in a Teacher Education Course. Teacher Education Quarterly, 33(2), 69-87.

Yokota, Junko. (1993). Issues in Selecting Multicultural Children's Literature. Language Arts, 70(3), $156-167$.

Young, Terrell A. and Ferguson, Phyllis M. (1995). From Anansi to Zomo: Trickster Tales in the Classroom. The Reading Teacher, 48(6), 490-503. 